\title{
A timeline of the racialist movement in the United States: A teaching tool
}

Article in Journal of Criminal Justice Education · November 2001

DOI: $10.1080 / 10511250100086211$

\section{CITATIONS}

4

3 authors:

Paul J. Becker

University of Dayton

11 PUBLICATIONS 57 CITATIONS

SEE PROFILE

Rebecca S. Katz

Morehead State University

22 PUBLICATIONS 166 CITATIONS

SEE PROFILE
467

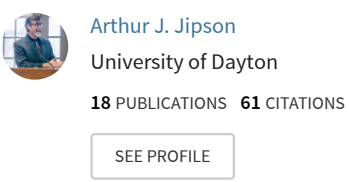

Some of the authors of this publication are also working on these related projects:

Book review. View project

Sociology of White Racialism View project 


\title{
A TIMELINE OF THE RACIALIST MOVEMENT IN THE UNITED STATES: A TEACHING TOOL*
}

\author{
Paul J. Becker \\ Morehead State University \\ Arthur J. Jipson \\ University of Dayton \\ Rebecca Katz \\ Morehead State University
}

\begin{abstract}
Since the 1995 bombing of the Alfred R. Murrah Federal Building in Oklahoma City, academics and the general public have shown increased interest in white racial extremist and other right-wing radical groups. The interest in understanding any form of extreme intolerance requires locating the historical development of the ideas, beliefs, and actions espoused through the legislation of miscegenation in our nation's history and by extremist organizations. A chronology, used as a teaching tool, reviews the unique strands of extreme beliefs and actions and connects these understandings to the growth of racialist and extremist ideologies in the United States. This timeline provides a tool for instructors and other interested individuals in gaining an understanding of such groups by locating key developments within the laws as well as within the white racial extremist movement. Thus this chronology focuses on legislative acts and Supreme Court decisions that mirror our nation's early white racialist history. Additionally, this timeline also provides information about other social movement forces that may have affected the white racial extremist movement.
\end{abstract}

The power in any scholarly writing is the utility embedded within it. We constructed this timeline partly out of frustration with our criminology and sociology courses because they lacked concise materials on the development of white supremacist thought and white racial extremism within the United States. We also noted that there was a lack of chronological resources that outlined the major events that catalyzed and characterized extreme white racist organizing and white supremacy.

"The authors would like to thank N. Prabha Unnithan and three anonymous JCJE reviewers for their helpful comments and suggestions. An earlier draft of this timeline was presented as part of a poster session at the annual meeting of the Academy of Criminal Justice Sciences, Albuquerque, NM, March 1998. All authors contributed equally to this timeline and are listed alphabetically.

JOURNAL OF CRIMINAL JUSTICE EDUCATION, Vol. 12 No. 2, Fall 2001

(C) 2001 Academy of Criminal Justice Sciences 


\section{ABOUT THE AUTHORS}

John D. Althausen received his $\mathrm{Ph}$.D. in Geography from the University of South Carolina in 1994. His research interests include monitoring of coastal habitats using airborne and satellite imagery, studying the impact of human development on the natural landscape, analyzing the perception and visualization of cartographic and imagery products, and spatial analysis of business, crime, and socio-economic patterns using geographic information systems. Dr. Althausen has published more than 20 papers in academic journals and proceedings. He is an Assistant Professor of Geography at Central Michigan University.

Paul J. Becker is an Assistant Professor of Criminology at Morehead State University, where he is affiliated with the Institute for Correctional Research and Training. His research interests include white racialist social movements; state and corporate crime; hate crime; community corrections; sociology of law; and the relationship between crime, deviance, and the Internet. Recent publications have appeared in American Journal of Criminal Justice, Research in Political Sociology, International Review of Law, Computers \& Technology, and The Justice Professional.

Julie Campbell is currently a doctoral student in Administration of Justice at the University of Southem Mississippi. Her research interests include women in policing and the treatment of predatory sex offenders by the criminal justice system.

Mary Jeanette (Hageman) Clement received her Ph.D. in Sociology from Washington State University and her dual degree in Social Work and Law from Virginia Commonwealth University and the University of Richmond. She has taught in colleges and universities in the states of New York, Washington, Kansas and Virginia Commonwealth University where she retired after 18 years. She has published 20 articles in journals, authored nine books, co-authored one, seven chapters in books and three course syllabi. Her most recent book is Juvenile Justice System: Law and Process, Second Edition. She is now the director of Bold Eagle, in Madison, Tennessee that provides professional organizational and personal growth services.

David O. Friedrichs is a Professor of Sociology and Criminal Justice at the University of Scranton. He is the author of Law in Our Lives: An Introduction (Roxbury, 2001) and Trusted Criminals: White Collar Crime in Contemporary Society (ITP/Wadsworth, 1996), and editor of State Crime, Volumes I and II (Ashgate, 1998).

JOURNAL OF CRIMINAL JUSTICE EDUCATION, Vol. 12 No. 2, Fall 2001

(C) 2001 Academy of Criminal Justice Sciences 
Shaun L. Gabbidon is an Assistant Professor of Criminal Justice in the School of Public Affairs at Pennsylvania State University-Capital College. He received his Ph.D. in criminology from Indiana University of Pennsylvania. Professor Gabbidon is the author of numerous journal articles, book chapters, and scholarly essays. He is also co-author (with Helen Taylor Greene) of African American Criminological Thought (2000) published by the State University of New York Press.

Cecil Greek is an Associate Professor of Criminology and Criminal Justice at Florida State University. His research and teaching interests include crime and media, information technologies and criminal justice, criminological theory, community policing, and distance learning.

Arthur J. Jipson is an Assistant Professor in the Department of Sociology, Anthropology, and Social Work at the University of Dayton. His research interests include Internet community, social organization and conflict, the racialist movement, extremist social movements, and organizational, state, and corporate crime. He has previously published in Research in Political Sociology, Popular Music, and Society and Child News. He has contributed chapters in Toward a Second Dimension, Sociology: The Small College Experience, and Danger in the Field. He has also recently co-edited a special issue of Sociological Focus on the White Racialist Movement and Hate Crimes.

Rebecca Katz received her Ph.D. from the University of Oklahoma. She is an Assistant Professor of Sociology and Criminology at Morehead State University in Morehead, Kentucky. Her research interests include developmental theories of crime, violence within the family, and gender and racial discrimination within the criminal justice system. Dr. Katz has recently published in Sociology of Crime, Law, and Deviance and the Western Criminology Review.

Kim Michelle Lersch is an Associate Professor of Criminology at University of South Florida. Her current research interests include police practices, police deviance, and citizen evaluations of the police.

Stephen L. Mallory is Chair of the Criminal Justice Department at the University of Southern Mississippi. Dr. Mallory's background includes 25 years as a narcotics agent with the Mississippi Bureau of Narcotics. His current research interests include transnational organized crime, informant development and management, and criminal justice education.

Adam J. McKee is a research fellow at the University of Southern Mississippi. His research interests include community and problem-oriented policing, research methodology, and evolutionary theories of justice. 
In an attempt to construct a timeline covering a large period of time, it is inevitable that there will be omissions; therefore, we have focused our attention on three forms of extremist thought and action that have dominated American culture - the American patriot movement (commonly referred to as the constitutional militia movement), the white racial extremist movement and the legislation and institutionalization of white supremacy. Thus the timeline focuses on social, legislative, and Supreme Court events that reflect the former legitimacy and institutionalization of white supremacist ideology once held in our society and its demise and rebirth through the introduction of later legislation, Supreme Court decisions, and social events. By extension, both the patriot movement and the more extreme white racialist movement have been and continue to become active social forces in American society with whom students and citizens must contend. Whether commentators are discussing the events of Ruby Ridge, Idaho; Waco, Texas; Jasper, Texas; Oklahoma City; or police racial profiling policies, we cannot escape a reference to militias, supremacists, or other racially motivated extremists who exist in either a high degree of tension within their community or exist with impunity in our community. We focus our timeline on these two movements and the institutionalization of white supremacy because of their influence, cross-fertilization, and parallel development.

\section{WHITE RACIALISM: A BETTER UNDERSTANDING OF WHITE RACIAL EXTREMISM}

Before discussing the term "white racialism", readers need to understand that the term "race" did not exist in the English language until the 16th century (Ferber 1998). It was initially used as a technical term in the 17 th century to define human groups. Finally, by the end of the 18th century, race became a common method of delineating human differences using a Northern European yardstick. Early views of racial inferiority argued that the Christian Bible supported polygenesis, the idea that different racial groups came from different human groups. However, not until the alleged era of "Enlightenment" in the 18th century, when scientific racism was born, was the notion of "inferior peoples of colors" given wider support when the naturalist Carolus Limnaeus described the races hierarchically with the Africans at the bottom. Other scientists followed suit and their work seemed to grow and gain more support after Africans were freed and became a stronger political force. Scientific racism appears "indistinguishable from the beliefs of contemporary white supremacists" (Ferber 1998: 30).

White racialism is an umbrella term that includes the widely divergent types of racist social movements and racist individual activity. The term originates among adherents in contemporary white supremacist discourse 
as a more adequate label for racist activity since it does not limit the described individual or group to one particular theme or view. Therefore, we use the terms racialism and white racial extremism to reflect various racist and anti-Semitic belief systems. The terms "white supremacist" and "white racialist" are not synonymous, although most research and anti-movement advocacy (e.g., the Southern Poverty Law Center, Anti-Defamation League, etc.) would suggest that they are the same. Given the wide variation in so-called white supremacy, we believe that the term racialism is much more inclusive of the variety of factions that exist within the broader context of what is labeled by observers and other scholars as white supremacy. More specifically, what is usually referred to as white supremacy often includes skinheads, members of different factions of the Ku Klux Klan, Christian Identity adherents, white separatists, and white survivalists. These varied organizations and belief systems are discrete forms of white racialism. They each possess some unique beliefs, strategies, values, and organizational styles that necessitate an understanding of their differences. Sound social and criminal justice policy and practice must be based on a comprehensive understanding of the different difficulties - and, in some cases, dangers - posed by different white racialist organizations and beliefs. To categorize these groups as the same obscures the real differences between them. Racialism refers to an ideology where the adherents' perspectives and activities are not only believed to be in the best interests of their socially constructed idea of race but that all other considerations are secondary. From a general racialist perspective, they are not racist(s), instead their beliefs and actions are perceived as supporting and protecting "one's own race" by - to use an oft-quoted remark - by any means necessary. Racialists are individuals who organize and strategize with individuals of like mind to build and direct social movements with an explanation of race at the heart of their endeavors. Since the term is selfdesignated and applied, we find it more appropriate than using non-movement actors interpretations. It is crucial to understand what the movement actors intend rather than proving them wrong. If criminologists and criminal justice practitioners are to understand extremism, we must seriously review and comprehend the views of extremists rather than dismissing them.

This distinction between the terms white supremacy and white racialism illustrates a need for more scholarship that reviews the history and foundations for the movement, and that succinctly draws together the various strands of white racialist practice. We believe that students and scholars need a source document demonstrating that racialism and the contemporary patriot movement are not historically unique and are, in fact, long standing traditions in American society. The idea must be conveyed that both kinds of extremists are social movement actors, both similar and 
dissimilar from mainstream social movement actors. Criminologists typically only discuss social movements in structural/functional ways by examining their measurable impact on society or, more directly, the criminal justice system rather than understanding racialist and patriot social movements and their members as socially, politically, and culturally constructed. Our approach presents a post-modern social movements alternative to a facile structural/functional deviance perspective that contends that extremist actors and institutions should be understood as pathological deviations to the normative structure of society. Neither racialists nor self-styled patriots should be defined exclusively based on the public perceptions of their actions. Instead, one must analyze historically the socioeconomic, cultural, and institutional links among self-designated and acting racialists and patriot movement members. These individuals or groups only become a social reality when individuals create similarly structured organizational and cultural structures, and develop the core elements of a discernable belief system. In other words, we have to understand and critique these groups through their stated goals and actions rather than their lack of fit with preconceived expectations. This information will be useful in a variety of courses including: general criminology; criminal justice; social deviance; courses that examine the intersection of race, class, gender and crime; sociology of the law; domestic and foreign terrorism; general social inequality courses; inequality and the criminal justice system; and environmental criminology.

We believe that a well constructed timeline stresses the dialectical role of human agency and social structure in determining how racialist social movements become socially active, and assists in defining the scope and structure of the resulting collectivity created by organizing by extremists. Standard discussions of so-called white supremacy, like that of anti-movement organizations such as the Southern Poverty Law Center, neglect a full appreciation of social structure since they assume that membership within these groups is an inevitable consequence of individual pathology or unique adaptation to severe social problems. It is important to note that extremists are engaged in the same attempt to understand and categorize their social and individual experience as are non-extremists. The same social structures and social organizations that produced conventional institutions and laws that have socially controlled, criminalized and denied civil rights to people of color have also produced extremists. Anti-movement organizations and watchdog groups engage in a phenomenology of enemy construction that serves their political ends in arresting racial and political intolerance but tend to dehumanize these extremists.

We assert that a timeline begins to solve the problems associated with both overestimation and underestimation of racialist and militia activity by directly outlining the past actions and intersections of both within a historical context. We also believe that a timeline illustrating the development of 
racism and political intolerance in their varied forms, beginning during the initial construction of the constitution in the United States, demonstrates the power and influence of these ideas on American society. Further, racism and patriot movements were not just the result of individual and motivational factors but also of social structural conditions we have alluded to these movements arose out of discontent and from the beginning of the end of institutionalized white supremacy. For example, racialist movements arose because the economic and historic context created a cultural climate in which individuals became receptive to the varied white supremacist and white racist messages, particularly as institutionalized white power began to erode. As we demonstrate below, these messages have been promulgated in different time periods by varied groups: slave owners, the government, the Ku Klux Klan, the Christian Identity movement, the Posse Comitatus, and by some members of the so-called patriot movement. These successful organizing techniques resulted not just from shared personal understandings, but also social connections, organizational conditions, and the historical opportunities available to these actors. This success, in turn, triggered pressures for uniformity across the racialist movement, even when this excluded viable and possibly more effective alternative strategies and organizational forms. In other words, new racialist organizations followed the successful strategies of not only other mainstream social movements (e.g., the civil rights movement), but also of previously successful extremist organizations. A timeline not only demonstrates the ebb and flow of particular actors but also illuminates the ways in which white racialists changed their strategies and organizing tactics after seeing other organization's successes (e.g., David Duke's entry into mainstream politics or white racialist use of the Internet).

This research was conducted on the development of the racialist and patriot movements in the United States, the role of these movements in American life, the key individuals associated with the contemporary white racialist and patriot movements, and the relationship between these extreme social movements and the American political economy. This work contains one primary objective: listing the major events in the development and transformation of these movements throughout American society in chronological order to advance understanding of white racialism.

\section{METHODS}

This timeline shows the progression of white racialist and patriot thinking beginning with the development of the American constitution. An informal content analysis of important works in the areas of white racialism, the patriot movement, and extremism has produced a series of significant dates that outlines the development and organization of institutionalized white supremacy and white racial extremism. However, it is important to acknowledge that any timeline is relative. While we may have omitted 
some important dates and actions, we have tried to include what we and other scholars and commentators have determined to be pivotal events associated with both institutionalized white supremacy and the racialist movement. In using the literature on white racialism, we have focused our efforts on dates of historical importance to assist in student comprehension of the history, organization, and overall development of the institutionalized white supremacy and the white racial extremist movement. The historian Paul David (1989) refers to these important dates as "historical junctures" where the organization, members of the organization, and the overall movement are all affected by the outcome. In these historical junctures, different trajectories are possible for the movement and its influence on society (David 1989). We are attempting in the brief outline that follows to list and explain the centrality of the outcome of these historical junctures on the white racialist movement.

One historical juncture is the creation of the modern constitutional militia movement. Given the interconnection of the patriot and white racial extremist movement, it is also worth noting that there are selected dates and actions in the timeline below that relate to both the development of the non-racialist sectors of the patriot movement and the white racialist social movement proper. Given the entanglements and intertwining of these two movements, these dates are few but significant to the future trajectory of both movements. One only has to note the influence of the posse comitatus, which was formed in 1969 by Henry Beach and William Potter Gale, as demonstrative of the linkages (for a fuller discussion of the origins and influence of the posse comitatus, see Corcoran 1990). Our goal is to integrate a variety of sources of information revealed through our own research and preparation to teach classes. We have relied heavily on a variety of sources including newspapers, news magazines, internal movement and anti-movement sources, and scholarly journals and books in the construction of this timeline of the racialist movement. In order to include an item in the timeline, at least two sources of information had to refer to the incident as pivotal and associated with the patriot movement, white supremacy, or racism. While not all events of significance to white racial extremism are listed below, we believe that the events that are listed are critical to understanding white racial extremism in the United States. These sources included scholarly works as well as investigative journalistic reports and reports of watchdog organizations. Our work is intended to provide an easily accessible teaching tool and to better inform students and colleagues alike that, unfortunately, racial extremism is alive and well in our society and has been present since our nation's birth. 


\section{THE BEGINNING: THE INSTITUTIONALIZATION OF WHITE SUPREMACY THE AMERICAN SOCIETY}

Our timeline begins with the development of the United States' Bill of Rights. We include the following discussion to inform readers that a critical reading of the construction of the Bill of Rights illustrates that elements of white racialism and the patriot movement begin at the birth of American political structure. Although later civil rights amendments to the Bill of Rights were intended to create greater political enfranchisement and democratic participation, the document itself also institutionalized racialist beliefs for a time. For example, one passage in the Constitution limited black males to three-fifths the status of white males, while black women were afforded even less value compared to white males. This clearly illustrates how white racialism or white supremacy was legally institutionalized in this nation's early history. Additionally, United States history is replete with examples of attempts to socially control or eliminate threats to white power. These attempts include the genocide of the American Indian, Jim Crow laws controlling the movement and freedom of African Americans, attempts to control both Mexican immigrants and Chinese immigrants with unique wars on drugs, such as the anti-opium campaign and the anti-marijuana campaign and the more recent disparity in crack-cocaine laws.

In light of the history of the institutionalization of white supremacy, we believe the baseline from which to interpret these white racialist acts requires the post-modern analysis of one particular constitutional amendment. The Second Amendment has been interpreted by post-modernists as clear evidence of the Constitution's white racialist origins. However, more traditional legal scholars have somewhat different views. Specifically, traditional constitutional scholars continue to promulgate one of two views, the collective rights view and the individual rights view. The Second Amendment to the Constitution reads as follows: "A well regulated Militia, being necessary to the security of a free state, the right of the people to keep and bear Arms, shall not be infringed."

The post-modernist view posits that a variety of "other historical texts must be explored as well as conducting an analysis of the community of readers who interpreted those texts" (Cornell 1994: 4). Cornell clearly contends that a post-modern view of the development of the Constitution sees its producers as representative of a plurality of positions rather than a simplistic dualism of the anti-federalist and the federalists. Moreover, Bogus' historical post-modern interpretation reflects that the Second Amendment was the result of the "slavery compromise" made between the colonies of the north (the federalists) and the colonies of the south (the anti-federalists). In other words, the Second Amendment, including the construct of a state militia and the right of those members of the militia to bear arms, was the product of the slave owners' desire to maintain and legitimize racialism 
(Bogus 1998). Although Cornell does not make this precise claim with regard to racialism, he does review a number of historical documents and concludes that a literal reading of the idea of individual liberty for all was not necessarily an important issue in either the federalist or the anti-federalist camp. This was particularly true with regard to the civil rights of a number of disenfranchised groups including women, African Americans and even non-Protestants in some cases. Although the social production of the Second Amendment was couched in the language of an individual rights issue to protect the pubic from federal government tyranny; in order to avoid revealing the real goal of maintaining white supremacy and the control of African Americans (Bogus 1998). Thus the rhetoric of the antifederalists was quite different from their behavior (Cornell 1994). This compromise amendment facilitated the southern states' maintenance of control over slaves through the armed militia, or what was then called the "slave patrols." These were armed white men who regularly surveyed the countryside ensuring that blacks were not going where they should not or gathering in nonwork related groups. These groups of armed white men were ready to respond to any threat of rebellion by slaves or among slaves at any time (Bogus 1998). Thus the individual right to bear arms as a fundamental individual liberty to prevent government tyranny was not an inclusive ideology representative of all the anti-federalists (Comell 1994). Both individual liberty and state and federal authority were socially constructed in occasionally contradictory ways. For example, by the middle of the 18th century, Virginia, Georgia and South Carolina each had slave patrols that were regulated and had become the responsibility of the militia. Secondarily, this amendment ensured that the new federal government would never limit that right or infringe upon the right of white southerners to own or control slaves, women, and British loyalists in some cases. Pennsylvania anti-federalists drafted the loyalty test for Quakers and Germans, forcing them to make loyalty oaths to America and not the United Kingdom. Many northern and southern anti-federalists drafting the Bill of Rights were from the elite class while southern anti-federalists were elite slave owners. The anti-federalists did not represent all the attitudes of the common people but shaped the republic because of their class and status positions (Bogus 1998; Comell 1994).

However, more traditional legal scholars are referred to as either the collective rights supporters or the individual rights supporters camp. First, the collective rights supporters' camp views the reference in the Second Amendment to militias as referring only to the state militias. However, the individual rights supporters' camp views the reference in the Second Amendment to militias as the right of all citizens to keep and bear arms, regardless of militia membership. The federal courts have not adopted either of the above views (Doughtery 1995). Other constitutional scholars 
further view that the First Amendment protects the speech and associational activities of citizen militias (Larissa 1996); while on the other side, other constitutional scholars view private citizen militias as constitutionally unsupported (Williams 1996; Kates 1986). Williams (1996) views the Second Amendment as supportive of the individual right to own weapons. However, both of these views posit what is called the insurrectionist perspective, which espouses that the militia was to serve as a resistance or deterrent against the use of the federal standing army against the states, as England had already done to the colonists (Doughtery 1995). The militia was to act as an internal police force at time when there were none. The term posse developed from posses Comitatus which referred to the entire population of a county or parish above the age of fifteen whom a Sheriff could summon to assist and aid in keeping the peace or in pursuit of law breakers or to arrest felons (Doughtery, 1995).

We view the initial Second Amendment compromise as a part of an ongoing social process that has protected white racial privilege and has continually manifested itself in different forms throughout American history. The present timeline attempts to demonstrate how, as these institutionalized methods of social control have waxed and waned, they led some citizens to form and join social movements for the advancement of white racialism. The timeline includes the most significant actions and events within the American patriot movement because some current militia organizations and other white patriot groups support white racialism. These groups are not only supportive of the anti-federalist position but appear to be supportive of the belief that the Second Amendment right to bear arms will facilitate the reinstatement of the white race as the primary control of the federal government (Stern 1995; Doughtery 1995; Larissa 1996; Dees and Corcoran 1996; Daniels 1997). An important caveat is in order: We do not contend that all citizens' and constitutional militias are racialist, however, the two movements remain deeply intertwined and appear to be associated. Thus some racialists have formed or joined militias to advance their cause (s).

A final note before beginning the actual timeline is to emphasize that we do not claim that this timeline is all inclusive or complete. We took on this project with the advance knowledge that by its very nature, there will be omissions and such a project cannot be completed to the satisfaction of everyone. We have selected certain areas to focus on, discussed in our introduction, and other entries included will be based on unintentional authors' biases. Because of the inevitable omissions, we encourage those who use this timeline as a teaching tool to supplement it with topics of interest to the instructor. A timeline is always changing and expanding, and we welcome comments and suggestions on this version of A Timeline Of The Racialist Movement In The United States. 
$1787:$

1792:

1830:

1840-1860:

Mid-19th Century:

Mid-19th Century:

$1854:$

1861:

1863 :

1865:

1865:

1865:

1866:

\section{THE TIMELINE}

Constitutional Convention, development of the Bill of Rights designed originally by and for free white male property owners, not women, African Americans, other people of color, or non-Christians. Throughout slavery in the South it was common for white slave masters to rape black female slaves. This event was used as a weapon of domination, repression and demoralization of the black people. The Militia Act: This act specified that the traditional militia consists of all able bodied white males and required each militiaman to supply his own weapons. Constitutional scholars argue that this act created two groups or types of militias, they are described as follows:

1. The organized militia, which consists of the National Guard and the Naval militia; and

2. The unorganized militia, which consists of the members of the militia who are not members of the National Guard or the Naval militia ("all able bodied white males between 17 and 45 years to provide himself with a good musket or firelock. ..") (Doughtery 1995).

Indian Removal Act authorized the forced march of the Cherokee, Chickasaw, Choctaw, Muscogee (Creek), and Seminole Nations to Indian Territory over the objections of the Supreme Court of the United States.

Lynchings in the South typically involved victims who were white abolitionists.

The Christian Identity Movement claimed that white Christians were the "true Israelites," that Jews were the offspring of Satan, and that blacks and other minorities were "pre-Adamic" or were of another specifies of subhumans created before Adam and Eve (Barkun 1994, Ezekiel 1995, Daniels, 1997: 28-29).

American scientists Louis Agassiz and Samuel George Morton argued that whites were the superior race and that pologenesis, or the separate development of the races, occurred and that race mixing or miscegenation was dangerous, thus segregation was necessary.

Count Joseph Arthur de Gobineau wrote "Essay on the Inequality of Human Races" stating that race mixing would lead to the demise of humanity.

The American Civil War begins.

The Emancipation Proclamation was signed by Abraham Lincoln promising "that all persons held as slaves [within the rebellious states] are, and henceforward shall be free." However, there were limitations including that it only applied to states that seceded from the Union and the freedoms promised was conditional on a Union victory (Featured Document: The Emancipation Proclamation.)

The Civil War ends.

December: The Thirteenth Amendment to the United States Constitution was ratified, abolishing slavery.

Freeman's Bureau Act assigned the right for allotment of land to black males only; black women could only claim the land if they were single.

Forty-six African Americans were killed when their schools and churches were burned by a white male mob in Memphis, Tennessee. 
1866:

1868:

1870:

1871:

1880s:

1880s:

1882:

$1882-1946$
$\mathrm{K} u$ Klux Klan was formed in Pulaski, Tennessee by six young returning Confederate officers who called it a secret social club. The activities of the group included harassing newly freed African Americans. Membership included men of all classes of Southerners with leaders coming from the wealthy classes. The primary targets of the early Klan included blacks who became economically independent, politically active, or those who actually tried to speak to white males, or who "appeared" to pursue white women sexually. Between 1868 and 1871 the Klan lynched over 400 African Americans in the South. Lynchings also included the sexual mutilation of black males intended as a method for emasculating black men and claiming white and black women as all belonging to white men. In 1868 branches of the KKK were established throughout the South.

The Fourteenth Amendment was ratified, stating that all persons born or naturalized in the United States were citizens whose rights could not be abridged without due process of law. Additionally, this act said all such persons had equal protection under the law.

The Fifteenth Amendment to the constitution was passed, stating that the right to vote cannot be denied because of race, color, or previous servitude.

Anglo-Israelism ideology is born with the publication of Edward Hine's "Identification of the British Nation with Lost Israel" in England. This theme explains that the original Israelites left the Middle East in $700 \mathrm{BC}$ and traveled to the British Isles. These people, all white, are called the real or true Jews. Hine claims that the blacks and the Jews are direct descendants of Satan. The first Jew was Cain, the son of the serpent, or Satan, and Eve. Furthermore, Hine wrote that the ". .'yellow race, the brown race and the red race'... . were created on the third day and were not given souls while Eve and their seed were given souls and were created on the sixth day" (Daniles 1997: 28-29). After the end of the military occupation of the South, segregation efforts hastened.

Collective violence aimed at Chinese and blacks by white Americans. Lynchings of blacks did not reach the same height as in 1860s but one count indicated 106 blacks were lynched. Lynchings also included sexual mutilation of black males.

The Chinese Exclusion Act was passed, suspending the immigration of Chinese laborers for 10 years and barring Chinese naturalization. These limitations were designed to control Chinese access to what was perceived as jobs belonging to whites. At this time the growing nativist movement existed under the premise of excluding the possibility of any new generations of Americans by limiting real Americans to those who were born and raised here or "natives".

Five thousand people were lynched in the South, an overwhelming number of which were black males. The myth of the black male rapist was promoted at this time to justify these lynchings. 
1887:

1896:

Late 1800s:

1900s-1920s:

1903:

1909:

1910:

1915:

1916:

1917:

1920:
The opium drug wars began with laws designed to criminalize the smoking of opium, the method predominantly used by Chinese, while European Americans who drank opium remained non-criminalized. This occurred as the myth was that smoking opium made the Chinese work harder, thus becoming a greater threat to white jobs.

Plessy v. Ferguson decision by the U.S. Supreme Court ruled that public facilities could separate the races, if the facilities remained separate but equal.

Nathaniel Southgate Shaler, a geologist and paleontologist, and zoologist Edward Cope, editor of the American Naturalist, each posited that Negro's were less intelligent. It was thought that intellegence was carried in the blood and if Negro blood was mixed with whites, it would contaminate the white race. It was also believed that only one drop of blood made someone non-white, an issue that was later legislated.

Collective violence peaked again with victims being predominantly black and the perpetrators being white European Americans. The 19th century Feminist Movement was also perceived as a threat to the powerful, rich white males. These white males feared that white women and black women would unite and become a threat to white male power.

The Dick Act attempted to restore the usefulness of the state militias by developing two branches of the militia, the organized militia which became the National Guard and the unorganized militia. Congress has never explicitly defined the role of the unorganized militia; however there are current statutes that provide for civilian firearms training as a part of the Civilian Marksmanship Program (Doughtery, 1995).

The NAACP is formed by W.E.B. Dubois and others to fight for the civil rights of people of color.

Numerous segregation statutes, or Jim Crow laws, were passed in southern states that included laws requiring separate seating on public transportation and separate public facilities as well as laws prohibiting interracial marriages. Lynching remained widespread in the early years of Jim Crow laws but became less frequent after these laws became firmly institutionalized.

D.W. Griffith's film "Birth of a Nation" is released. Considered by many to be a masterpiece, the movie based on Thomas Dixon's 1905 novel "The Clansman," portrayed a sympathetic account of the Ku Klux Klan while promoting many stereotypes about African Americans.

"The Passing of the Great Race" by Madison Grant is published. In the book Grant calls for America to abandon the practically open-door immigration policy at that time. He also promoted a eugenics program that favored the "Nordic" races. Grant would go on to be president of both the Immigration Restriction League and the Eugenics Research Association.

Literacy tests for immigrants were introduced in response to nativists' fears and anger about the prospect of losing jobs to immigrants.

The Nineteenth Amendment to the Constitution was passed giving women the right to vote. 
1920s:

$1920 \mathrm{~s}-1930 \mathrm{~s}$

1921:

1924:

1933:

1934:

1939:
KKK political activity increased. By 1925 the Klan, now promoting anti-immigration sentiments, claimed over five million members. After the 1920s membership in the KKK dropped to 40,000 after several scandals and groups, such as unions and veterans' groups, denounced the Klan (Sims 1978; Ridgeway1990; MacLean 1994; Wade 1987). Henry Ford is given a copy of the "Protocols of the Elders of Zion", a forgery based on an earlier nineteenth century novel about politics and Napoleon. All references in the original novel were removed and replaced with the word Jews whose elders sought to secretly control the world. Henry Ford began a mainstream campaign against the "International Jew" in his independent newspaper the "Dearborn Independent." The articles have been subsequently reproduced in book form along with the Protocols (Stern 1996). This is important as it reflects the diverse nature of racialism, aimed at many groups not merely African Americans, but also Jews (Barkun 1994).

A drug war against Mexicans was created by laws criminalizing the smoking of marijuana, a drug used by many Mexicans. Thus attempts were made to criminalize only the behavior of Mexicans as they were considered a threat to white jobs and were paid substantially less than whites.

Three hundred representatives from around the world attend the Second Eugenics Congress at the American Museum of Natural History in New York City.

The National Origins Act established the national origins quota system. This restriction on immigration favored the admission of northern and western Europeans.

Madison Grant's "The Conquest of a Continent" is published, encouraging the social separation of whites and nonwhites.

The National Firearms Act was passed during the Prohibition era as the result of public fears about gangster activity. This law made it illegal for an individual to transport specific types of weapons over state lines without a proper registration (Doughtery 1995). This law is pivotal as its passage remains important to some racialist militia groups who claim that the federal government's attempt to control the "individual right to own firearms" is form of government tyranny (Williams 1996; Freilich, Almazar, Rivera 1999).

Miller v. United States. In this federal case, two men were charged with violating the National Firearms Act by transporting an unregistered sawed-off shotgun from Oklahoma into Arkansas. The Supreme Court, using the 18th century definition of a militia, determined that the men were within their rights to carry the weapon. The court also created a test to decide whether someone's Second Amendment rights have been violated, by determining whether the weapon has "some reasonable relationship to preservation of efficiency of a well regulated militia" (Doughtery 1995). 
1940s:

1942:

1943:

1950s:

1954:

1960s:

1960s:
Reverend Gerald L. K. Smith founded the Christian Nationalist Crusade and the Committee of "One Million." They used Ford's ideas from the International Jew to preach about anti-Semitic Conspiracy theories. By the 1940 's, Smith was a leader in the Christian Identity Movement (Stern 1996). Again, this is important relative to the forthcoming Militia movement that has the central tenet of federal gun control. Moreover, some of these organizations are racialist groups (Freilich et al 1999).

Cases v. United States: This was another criminal case under the Federal Firearms Act. This court overturned the previous test and stated that they "did not intend to formulate a general rule." This case also narrowed the Supreme Court's definition of militia to include only the National Guard. The court feared that the former Miller case would lead to private citizens owning modern weapons of mass destruction. The court also ruled that federal courts should decide each Second Amendment case on its own facts (Larissa 1996).

Chinese Exclusion Laws repealed.

KKK membership dropped to 10,000 , which we suggest is the result of the good post-war economy where jobs were plentiful and young white male war heroes were hailed back to their jobs that had been temporarily "lost" to women and people of color.

Brown v. Board of Education, Topeka, Kansas. The U.S. Supreme Court struck down mandatory segregation of public schools along racial lines, saying that this was unconstitutional. The U.S. Supreme court ruled that segregation violated the Fourteenth Amendment, which states, "no state will deny to any person within its jurisdiction the equal protection of the laws." The court based its decision on the argument that segregation inevitably labels blacks as inferior. At this time segregation was mandatory in seventeen states. It is important to note that this did not affect segregation in other public facilities.

The U.S. Public Health Service forcibly sterilized several thousand American Indian women without their consent. The Minutemen, a private army to fight communism through guerrilla warfare, is formed. Their ideology, like that of the current militia movement, professed similar conspiracy theories. The November 1963 issue of the Minutemen publication, On Target, states, "Most Americans do not realize that a number of United States Army Troops were turned over to the United Nations command to make practice seizures of a number of American cities as far back as 1952 . . When these facts are known, however, the possibility of our personal firearms being confiscated by the end of 1965 seems less fantastic. The actual procedure discussed calls for the United States to be divided up into areas of approximately . . .states each. . . each of these areas is to be sealed off with troops and systematically searched until all possible arms are found and confiscated“" (Stern 1996: 48-49). 
1961:

1963:

1963:

1963:

1964:

1965:

1966:

1967:

1968: November 18:

1968:
Dennis v. United States. This case determined that, if there is a clear and present danger of violence or civil disorder, the government does not have to wait for the event to occur to make arrests or press chargers. This is often referred to as the beginning of the Instructional Ban. Many states have developed these bans which delineate that persons who train militia members in the use of weapons or techniques capable or causing injury or death are guilty of a felony. Usually, this law requires that the person providing the training knows, or has reason to know or intends for the training to be unlawfully used in the furtherance of a civil disorder (Larissa 1996).

Civil rights leader and NAACP field secretary Medgar Evers was murdered in front of his home. His killer, a self-reported white supremacist, was not convicted until 1994.

Birmingham, Alabama, 16th Baptist Church was burned after a bomb detonated on Sept. 15th, killing four little girls and injuring sixteen others. In 1977, Robert Edward Chamblisswo is convicted on one count of murder. In 2001. Thomas Blanton is convicted of four counts of first degree murder and sentenced to life in prison. Another defendant, Bobby Frank Cherry, has his 2001 trial postponed due to mental incapacity.

Voting Rights Act suspended the use of literacy or other voter qualification tests for voting, authorized federal voting appointees to register African Americans in areas not meeting certain voter participation levels. This act also provided for federal initiation of court suits to hear discriminatory poll taxes charged some blacks before voting. Civil Rights Act of 1964 expanded voting rights for racial minorities and outlawed discrimination against minorities in employment and the use of public facilities and accommodations.

The Immigration and Naturalization Act Amendments of 1965 , aimed to eliminate racism in immigration pollicies, repeals the national origins quotas.

President Johnson issued Executive Order 11246, directing all federal contractors to have affirmative action programs.

Klan membership increased to 55,000 , apparently as the result of the new civil rights legislation and the ongoing perceived threat of the growing Civil Rights Movement (Dees and Cochran, 1996).

A rocket filled with Minuteman literature exploded in Houston across the street from Houston's downtown Federal Building.

The Civil Disobedience Act 1968 was passed. This act has been used to suppress civil rights activities of some groups who are perceived as threatening to the existing order. Some militia groups might argue this too is an infringement of their right to fight government tyranny, if it becomes necessary (Doughtery, 1995). 
1969:

1969:

Posse Comitatus is formed. This was an armed right-wing group founded in Portland, Oregon, which was active through the mid 1980s. Some of their written material included the following statements, “. . Yahweh our father is at work setting the stage of the final act against the Christ-murdering Jews and their father, Satan. . . America is the Zion of the bible Prophecy. . our nation is now completely under the control of the International Invisible government of World Jewry. . . our U.S. Constitution, our Bill of Rights and our Christian Law has been trampled beneath the mire and the filth of the International Money Barons of high finance who now control the government of these United States." This group opposed gun control and some refused to pay federal taxes and state taxes, claiming that taxation is a violation of the Constitution (Abanes 1996; Aho 1990; Stern 1996: 50-53).

Brandenburg v. Ohio. The Supreme Court ruled that Ohio's Criminal Syndicalism Act was unconstitutional. In this case, a leader in a local KKK group was captured on tape by media crews making racist statements about Jews and African Americans, also other statements advocating violence against both groups. The defendant appealed the conviction, claiming that the act violated the First Amendment. The court found, that "constitutional guarantees of free speech. . . do not permit a State to forbid or proscribe advocacy of the use of force or law violation except where such advocacy is directed to inciting or producing imminent lawless action" (Larissa 1996: 613).

The Christian Identity Movement moves to Hayden I ake, Idaho, where Richard Butler's church becomes known as Aryan Nations (Barkun 1994).

Minuteman leader Robert DePugh was convicted and jailed, leading to the disintegration of the organization (Jones 1968; Stern 1996).

The Equal Employment Opportunity Act prohibited employment discrimination based on race, color, national origin, religion or sex in state or local governments.

United States v. Featherston. In this case the plaintiffs who were members of the Black Afro-Militant Movement were instructed on making explosive devices for the purpose of preparing for the "coming revolution" (Larissia 1996: 621). The original federal court decision claimed that members of the group knew that such explosive devices could be used in promoting or causing civil disorder and thus had committed a federal crime. The plaintiff's appeal focused on the phrase "having reason to know" in the Civil Disobedience Act, claiming that the phrase was too broad. The court decided that the statute required proof that any violator did know or intent that such training would be used in the advancement of a civil disorder. The court cited another case of Gorin v. United States, when that court stated that the act must occur in bad faith for any sanctions to be applied.

1974: KKK reached its contemporary nadir at 1500 members (Dees and Corcoran 1996). 
1977 :

1977:

1978:

1978:

1979, November 3:

1980s:

1980:

1980:

1980:

1981:

1981, March 21:
United States v. Oakes: The court decided that although the defendant was a member of the unorganized Kansas State Militia (all able-bodied male citizens between the ages of 21 and 45), membership in a military organization other than the organized militia of the state (the National Guard) did not entitle the defendant to any constitutional protection (Doughtery 1996).

Gorden Kahl, member of the Posse Comitatus was convicted of tax evasion.

The Tumer Diaries is published. The book is written by Andrew MacDonald, a pen name for William Pierce, leader of the Neo-Nazi group, National Alliance. The fictional book describes the exploits of Earl Turner, a member of a secret racist group called The Order, and events in the 1990s leading to a race war. The book becomes standard reading for many members of the extreme right, influencing individuals from Robert Matthew's to Timothy McVeigh.

University of California Regents v. Bakke. The U.S. Supreme Court ruled that affirmative action policies that included quotas for minorities or women were unconstitutional.

In Greensboro North Carolina, during an anti-Ku Klux Klan rally, five members of the Communist Worker's Party are killed by Klansmen and Nazis. The defendants are acquitted in subsequent state and federal criminal trials; however, in 1985 several defendants are found liable in a civil trial for nearly $\$ 395,000$.

Federal war on drugs penalized crack users, who are predominantly minority and poor, more severely than powder cocaine users, who are more likely to be white and wealthy. Crack users with 5 grams are sentenced to a mandatory five years, while cocaine users with 500 grams are sentenced to mandatory five years.

Klansman Tom Metzger wins a Democratic nomination for a U.S. Congressional seat, but loses in the general election. Former Klansman Gerald Carlson wins the Republican nomination for a U.S. Congressional seat, but loses in the general election.

The National Association for the Advancement of White People formed by David Duke after he broke from the Klan. This organization integrated conservative thought against welfare, affirmative action and school integration with white supremacy.

Thirty-Eight states have established laws regulating or prohibiting the formation of citizen militias, training associated with militia activities, and the participation in such training activities. Militia member again claim that this is proof of ongoing federal attempts to control the individual right to bear arms.

The Anti-Defamation League of B'nai B'rith publishes a model for hate crime legislation.

Members of the United Klans of America lynch Michael Donald. 
1981, November 3: Klanwatch is formed as a division of the Southern Poverty Law Center when director Morris Dees files a civil suit against members of the Invisible Empire. The suit was in response to an attack by Klan members against civil rights marchers in Alabama in 1979.

1982:

1983:

1983, February 17: Near Medina, North Dakota, federal agents attempted to arrest Posse Comitatus member Gordon Kahl for violating probation on tax evasion charges in Texas. This attempt resulted in a shoot-out, leaving two United States Marshals dead and three other officers wounded. Again, some militia groups utilize this event as a method of garnering support for the notion that the federal government is becoming tyrannical.

1983, June 3:

1983, September:

1984: Summer:

1984, June 18:

1984, July 19:

1984, December 8:

Tom Metzger forms W.A.R. (initially White American Resistance, but currently known as White Aryan Resis-

Gordon Kahl is found hiding out in Arkansas. An attempt to arrest him results in the death of a local sheriff. Federal agents set Kahl's hideout on fire, but he never comes out. Kahl becomes a martyr to the militia and white racialist movement. the Aryan Nations, is formed. The leader of the group, Robert Mathews, is inspired by the book The Turner Diaries. Money earned in robberies of banks and armored vehicles was allegedly distributed to white supremacists across the country. San Diego.

Alan Berg, a controversial radio talk show host, is assassinated in Denver by members of The Order. taking $\$ 3.8$ million dollars.
Fisherman's Association v. Knights of the $\mathrm{K}_{\mathrm{u}}$ ux Klan (the Military Arm of the KKK, a private army known as the Texas Emergency Reserve). The military arm of the KKK sought to intimidate and harass Vietnamese fisherman. The TER conducted military training and participated in an armed boat ride through a commercial waterway, conspicuously displaying their weapons. An effigy of a Vietnamese fisherman was hung from a rear deck rigging. The court issue a permanent injunction against the TER prohibiting them from associating, parading or training as a military organization. The court also determined that the TER's activities were ontside the scope of the First and Second Amendment projections. The court indicated that fighting words are not worthy of constitutional protection and that the freedom to associate is not inclusive of a conspiracy or breaches of the peace. The court indicated that a militia is only viable if it is organized by the state. Louis Beam led the Texas Emergency Reserve and later became a theorist of the $1990 \mathrm{~s}$ militia movement and authored "Leaderless Resistance," a key tenet of the movement (Larissa 1996; Stern 1995).

The Order (or Silent Brotherhood), a secretive offshoot of

Tom Metzger's cable show "Race" (later named "Race and Reason" and seen nationally on cable access) premiers in

Members of The Order rob an armored car in California

Robert Mathews, founder of The Order, dies after a standoff with federal agents in Washington state. 
1985, December 30: 22 members of The Order either plead guilty or are convicted of racketeering charges.

1987, April 24: $\quad$ A Fort Smith, Arkansas jury indicted fourteen leaders of a white supremacist movement, included Richard Butler and Louis Beam (then a member of the Aryan Nations) and Robert Miles (a Christian Identity movement leader and former KKK member). They were charged with "sedjtious conspiracy," that is plotting to overthrow the government of the United States by force. Five of these people were also charged with a conspiracy plot to kill an Arkansas federal judge. All defendants were acquitted.

1987: February 13: Morris Dees wins a $\$ 7$ million dollar civil settlement against the United Klans of America in the lynching death of Michael Donald.

1988, October 25: $\quad$ Morris Dees wins a $\$ 950,400$ settlement for 53 plaintiffs, against the Southern White Knights of the KKK, for violence the group started during a civil rights march in Georgia in 1987.

1988, November 13: Three skinheads beat and kill an Ethiopian student in Portland Oregon.

1989, February 18: David Duke, former Klansman and founder of the N.A.A.W.P (National Association for the Advancement of White People), is elected to the Louisiana House of Representatives.

1989, November 5: The Southern Poverty Law Center dedicates the Civil Rights Memorial in a plaza outside its offices.

1990:

The Hate Crime Statistics Act is passed, requiring the Justice Department to collect and distribute occurrences of hate crimes.

1990:

1990, October 22: $\quad$ Morris Dees wins a $\$ 12.5$ million dollar civil suit against Tom and John Metzger (of W.A.R.) and the three skinheads involved in the killing of an Ethiopian student, when he shows that the skinheads were acting as agents of the Metzgers.

1990:

United States v. Verdugo-Urquidez: The Supreme Court stated that the Second Amendment's reference to the "the People" should be read in the same manner as in the First, Fourth, and other Amendments. This is interpreted as reflecting that militias are not privately organized or limited only certain people in the population, but are of the citizens of this nation. Again, many militia groups see such laws and cases as threats and indicators of government tyranny. They utilize such instances to support their argument for a return to only the first ten amendments to the constitution, thus denying civil rights to people of color and women and thus supporting social disorder, deviance, and sometimes racialism (Freilich et al. 1999).

1991, January 17: Randy Weaver is arrested as the result of a 1989 U.S. Bureau of Alcohol, Tobacco and Firearms sting operation set up to arrest Idaho white supremacists who had an alleged underground arms business. Randy Weaver allegedly sold an illegal sawed-off shotgun to an informant in October 1989. 
1991:

1992, August 21:

1992:

1992, September:

1992, October:

1993: February 28:

1993, April 19:

1993, Summer:

1993, June:
David Duke, former Klansman and founder of the N.A.A.W.P (National Association for the Advancement of White People), is defeated in a runoff for governor of Louisiana.

An 1I-day standoff begins at Ruby Ridge, Idaho, home of white separatist Randy Weaver, after a shootout leaves Weaver's 14-year-old son and a Deputy U.S. Marshall dead. Federal agents wanted Weaver for failing to appear in court on weapons violations. The next day, an FBI sniper kills Weaver's wife and Weaver eventually surrenders.

Klanwatch determines that there are over 362 white supremacist organizations in the United States with over 40,000 members (Daniels 1997).

Two weeks after Weaver surrendered, Bo Gritz who helped negotiate the surrender, articulated his platform for Presidency for the Populist Party, a group some scholars believe is racist and Anti-Semitic. Gritz discusses his opposition to the New World Order and later in the month he suggests that the United Nations is a "godless organization." He also suggested that the constitutional law was the only way to "continue our birthright" (Bock 1995; Dyer 1997; Hamm 1997; Walter 1995).

In Estes Park, Colorado, around one hundred and fifty members of various hate groups gather and, according to Klanwatch, this is a key point in the development of today's militia movement. Present were members of the following groups: Neo-Nazis, Christian Identity Adherents, Anti-abortionists, Ku Klux Klan, American Christian Patriots, and the Christian Crusade for the Truth. The following individuals were also present: Richard Butler, Louis Beam, Anti-Semite Red Beckman, and Larry Pratt of Gun Owners of America. Also present were members of traditional religious groups (Baptists, Presbyterians, Church of Christ, and Mennonite) (Ridgeway 1990; "The Rise and Decline of the Patriots" 2001).

In Waco Texas, federal agents attempted to arrest David Koresh, leader of the Branch Davidians, for weapons violations. The federal agents faced resistance that resulted in a shoot-out leaving four federal agents and six members of the Branch Davidians dead.

Federal agents attempt to raid the Branch Davidian compound at Waco, Texas, as a fire breaks out, killing 80 members of the sect. The incident is used to fuel the militia movement's claim that the government is tyrannical and needs to be overthrown. The date becomes a symbol of government tyranny for some members of the militia movement (Williams 1996).

The Brady Bill is enacted, requiring a minimum waiting (five days) period before purchasing a firearm. Some militia groups posit that any type of gun control law violates the Second Amendment and is evidence of government tyranny. This is used to support their denial of any amendments beyond the Bill of Rights (Williams 1996). The waiting period was later eliminated.

In Mitchell v. Wisconsin, the U.S. Supreme Court rules that hate crime laws that allow for penalty enhancements are constitutional. 
1993, July 8:

1993, July 15:

1994:

1994, January:

1994, February:

1994, February 15:

1994, March 10:

1994-1996:

1994, October:

1995:

1995:
An Idaho jury acquits Randy Weaver and Kevin Harris of murder in the death of a U.S. Marshal during a standoff at Weaver's Idaho home.

Eight alleged white supremacists are arrested in Los Angeles after an undercover investigation found that the group planned bombings and assassinations in an attempt to start a race war.

"The Bell Curve" is published. This "scientific treatise" written by Richard Hernstein and Charles Murray claims that minorities and the poor are inherently deficient intellectually.

Federal Assault Weapon Ban. This law has been used by patriot and militia groups to develop the ideology that the federal government wants to control the people by taking away their individual Second Amendment right to own a personal firearm. They utilize such instances to foment belief in only the first ten amendments to the Constitution, subtly advocating racialism (Williams 1996).

White supremacist Byron De La Beckwith is convicted of the 1963 murder of civil rights leader Medger Evers and is sentenced to life in prison. Beckwith had been tried twice previously, but in both trials all white juries were deadlocked.

Randy Trochman, John Trochman, and David Trochman organized the Militia of Montana (MOM) as a result of the passage of the Brady Bill. Randy Trochman has attended Aryan Nations meetings and advocated that government taxation is unconstitutional. On January 26, 1992, Randy Trochmann declared his "Sovereignty" as a "free white Christian man" who believed in the "organic Constitution of the United States." MOM is considered the most significant militia group formed, and was the most active in terms of sending out militia propaganda in the United States (Stern 1996; Williams 1996; Dees and Corcoran 1996).

Eight hundred people came to hear the Trochmanns in Kalispell Montana.

According to the Southern Poverty Law Center, 441militia and 368 Patriot groups existed, and 137 had ties to white supremacist groups. Every state now has at least one militia group operating (Dees and Corcoran, 1996).

The SPLC creates the Militia Task Force in order to observe and record any possible racialist ideological developments in that movement or in specific organizations.

The federal sentencing commission recommends that the federal penalties for crack and cocaine be equalized.

United States v. Wright. The defendant in this case challenges his conviction for possession of two machine guns and three pipe bombs, based on an infringement of his Second Amendment rights. The defendant claims that he was a member of a North Georgia Citizen Militia and that his possession of those weapons was related to his membership in a 'well regulated militia' and that his possession of the weapons was protected under the theory that the Second Amendment confers the individual right to keep and bear arms (Larissa 1995). 
1995, January-March: Warrants were issued for the arrests of Montana Militia Members Rodney Skurdal and LeRoy Swcheitzer. Charges were "advocating crime, malicious damage to property and violence other methods of terrorism to accomplish political ends." Additionally, a federal warrant was issued for Marc Andra including charges of "intimidation and interference with federal officials." Gordon Sellner was charged with shooting a deputy sheriff on June 27 , 1992. Tom Klock of Cascade Montana was arrested for depositing phony money orders in the local bank that had been printed by local Militia of Montana freemen. Eventually, Randy Skurdal's property was confiscated for refusing to pay taxes.

1995, April:

1995, April 1:

1995, April 19:

Darwin Michael Gray, a supporter of Randy Weaver, was arrested for a plot to blow up a Spokane, Washington, federal courthouse with a fertilizer bomb.

Militia groups existed in thirty-six states, some of which maintained clear ties to white supremacist or racialist organizations (Freilich et al. 1999).

The Federal Building in Oklahoma City is bombed, killing 168 people. The bombing occurs on the second anniversary of Waco and brings to light the antigovernment militia movement fueled by incidents such as Waco and Ruby Ridge. Also on this date, Richard Wayne Snell, former Order member, was executed for the murder of an African American police officer (Stern 1996).

1995, April 21: $\quad$ First day of the conference of the Christian Patriots in Branson, Missouri. One of its leaders included Christian Identity Pastor Pete Peters. He claimed the bombing of the Oklahoma City Federal building, a few days earlier, was a government-sponsored event conspired to turn the public against the patriot movement.

1995, May:

Larry Harris, with relations to white supremacist groups and a militia sympathizer, was apprehended in Lancaster, Ohio, for buying bubonic plague bacteria by mail. Police found this material in his home along with grenade triggers, homemade explosives and detonating fuses.

1995, June:

Klanwatch Project reported that 131 individual militia groups existed in the United States, claiming that about 23 of these groups have relationships with racist organizations.

1995, July:

200 white supremacists and neo-Nazis from around the United States and Canada attended the annual Aryan World Congress near Hayden Lake, Idaho. This is a yearly event sponsored by the Aryan Nations (largest white supremacist group in our society). They launched an intelligence operation aimed at surveillance of those "enemies of their organization." They use a type of military acronym commonly utilized in the U.S. Army for intelligence reporting, called SALUTE. Similarly, the same SALUTE acronym and the same form was used in a militia convention in South Dakota, sponsored by the Tri-State Militia, an organization that has affiliates in over twenty states.

1995, August 15: The U.S. government settles with Randy Weaver and his family for $\$ 3.1$ million dollars and prepares to begin hearings on the incident in September. 
1995, November 2:

1995:

1995:

1995: November 18,:

1995: December:

1995:

1996:

1996:

1996:

1996:

1997:

1997, June 2:

1997, August:

1997, December:

1998, January 8:

1998, February 20-24:
Hearings in Federal House Subcommittee on Crime. Associate Director of Klanwatch, Brian Levin, reported that there were 272 militia groups within 48 states and that 66 of these groups have relationships with the white supremacists movement.

Proposed Bill H.R. 1899, 104th Congress 1st Session bill to amend Title 18, U.S.C. 231 (a) to prohibit the formation of private paramilitary organizations. Concerns surrounding this bill included the threat of militia groups, some with clear ties to racialist organizations.

The National Confederation of Citizen Militias was created to assist the various local militia groups in organizing, recruiting and retaining members. The organization states that it is non-denominational, non-political, and non-racial and aims to ally patriotic defense groups.

Self-proclaimed citizen militia conference was held in Macon, Georgia.

Private James Burmeister of Fort Bragg, North Carolina, was arrested after first taunting two black males with racial slurs and then shooting both men in the head with a semiautomatic handgun. Burmeister had copies of racist material in his off-base home.

The University of California Board of Regents voted to end considering race in the admission of students to colleges.

California voters approved Proposition 209 which bars the state from using race or gender preferences in educational admissions, public hiring or contracting.

Christian Identity adherents planned a meeting called Jubilee, in which militia and patriot organizers met and listened to others supportive of the militia cause. Speakers included Louis Beam and Christian Identity minister Pete Peters, organizer of the Estes Park meeting.

Church Arson Prevention Act was passed. This act made federal funds available to black churches to improve security and prevent attacks by extremists.

Personal Responsibility and Welfare Act provides, for the first time in history, limited social services available to immigrants.

The Federal Sentencing Commission recommends the federal sentences for cocaine and crack be equalized.

Timothy McVeigh was convicted in a federal court of eleven counts of murder.

Timothy McVeigh is sentenced to death.

Terry Nichols was convicted on one count of conspiracy and eight counts of involuntary manslaughter for his involvement in the Oklahoma City bombing.

Lon Horiuchi, FBI sniper, will stand trial in federal court on charges of involuntary manslaughter as a result of the shooting death of Vicki Weaver during the standoff at Ruby Ridge

Larry Wayne Harris, former member of the Aryan Nations, and William Job Leavitt Jr. are arrested in Las Vegas. The two are charged with possession of a dangerous biological toxin, initially thought to be Anthrax. Charges are dismissed when it is determined the substance is a animal vaccine for anthrax. 
1998, February 24: The Supreme Court rejects an appeal filed by FBI and US Marshall employees to protect them from a civil suit filed by Kevin Harris due to events related the Ruby Ridge standoff.

1998, May:

A judge dismisses the involuntary manslaughter charge against FBI sniper Lon Horiuchi in the shooting death of Vicki Weaver during the 1992 Ruby Ridge.

1998:

Washington State approved a ballot measure that bars the state from using race or gender preferences in educational admissions, public hiring or contracting.

1998:

1999, September:

A report by the Human Rights Watch concluded that race continues to play a large role in acts of police brutality.

Admission of using incendiary devices during the conclusion of the fifty-one day Branch Davidian standoff leads Attorney General Janet Reno to appoint an independent council to investigate the standoff.

2000, June:

A federal appeals court rules that FBI sniper Lon Horiuchi cannot be prosecuted for manslaughter. In August, the court announces it would reconsider its decision.

2000, August:

Southern Poverty Law Center co-founder and head trial counsel, Morris Dees, successfully sues the Aryan Nations and its founder, Richard Butler, for several million dollars. The suit amounts to financial ruin for the Christian Identity organization.

\section{CONCLUSION}

Understanding racialist social movements through only a contemporary economic or political context obscures a variety of historical continuities among racialist groups and confounds the various developmental relationships between such groups across time. We believe that this timeline provides an understanding of the organization, history, and future trajectory of racist extremism in the United States. While it does not analyze the interconnections of all of these events and actions, it does demonstrate the linkages between legitimate or institutionalized white supremacism, and links between the patriot and racialist movements.

As such, this timeline can serve as a useful primer to the white racial extremist movement. There is growing evidence from post-modern constitutional historians and critical scholars that forms of racialism were central to the development of the Bill of Rights as the anti-federalists and federalists originally formulated the Constitution. This is illustrated by constitutional scholars Bogus and Cornell who have analyzed a number of historical documents revealing evidence of the absence of all-inclusive motives for the civil rights for American groups among the writers of the constitution. This is most clearly revealed in the compromise of the Second Amendment and the omission of people of color and women from the Bill of Rights (Cornell 1994; Bogus 1998). Beard's (1968) controversial analysis incorporating the economic and masculine perspective that shaped the American 
Constitution, is central to contemporary critical analysis. The timeline further demonstrates that ideas that originated within the white racialist movement have been incorporated into the mainstream of American political discourse (e.g., nature of the debates on affirmative action and welfare reform). Our socio-historical analysis of white racialism in the United States should also be replicated on a global scale to understand the nature of national competition on white racial extremism.

Although a recent compilation of essays by Kaplan and Bjorgo (1998) provides a compelling analysis of the socio-political and economic factors that lead to the simultaneous development of extremist racialist groups across the world, no socio-historical timeline is offered. However, Kaplan and Bjorgo's edited anthology clearly reveals that with the ever increasing ability to communicate rapidly and succinctly, white racialists promote their messages of ethnocentricity and racial hatred via the Internet (Weinberg 1998; Back, Keith and Solomos 1998). Future research must continue to investigate racialist groups directly through observation and content analysis of internal documentation. An in-depth review and analysis of the actual workings of the movement can further explain the process of formation and development of the racialist movement and provide assistance in the development of social policies that may aid in eliminating America's racialist organizations and ideology. We believe that the importance of this timeline lies in the phrase: those who do not clearly see and understand the past are doomed to repeat it. Additional future research needs to explicate the precise connections between many of the actions described in this timeline.

\section{REFERENCES}

Abanes, R. 1996. American Militias: Rebellion, Racism, \& Religion. Downers Grove, IL: InterVarsity Press.

Aho, J. A. 1990. The Politics of Righteousness: Idaho Christian Patriots. Seattle, WA: University of Washington Press.

Back, L., M. Keith, and J. Solomos. 1998. "Racism on the Internet." In J. Kaplan and T. Bjorgo (eds.), Nation and Race: The Developing Euro-American Racist Subculture, pp. 73-101. Boston: Northeastern University Press.

Barkun, M. 1994. Religion and the Racist Right: The Origins of Christian Identity. Chapel Hill, NC: University of North Carolina Press.

Barnes, R. D. 1992. "Standing Guard for the P.C. Militia, Or, Fighting Hatred and Indifference: Some Thoughts on Expressive Hate-Conduct and Political Correctness." University of Illinois Law Review 1: 979-995.

Bock, A. W. 1995. Ambush at Ruby Ridge: How Govermment Agents Set Randy Weaver Lp and Took His Family Doun. Irvine, CA: Dickens Press.

Bogus, C. T. 1998. The Hidden History of the Second Amendment. University of CaliforniaDavis Law Review (31)2:309-408.

Coates, J. 1987. Armed and Dangerous: The Rise of the Survivalist Right. New York: The Noonday Press.

Corcoran, J. 1990. Bitter Harcest: Gordon Kahl and the Posse Comitatus. New York. New York: Penguin Books.

Cornell, S. 1994. "Moving Beyond the Canon of Traditional Constitutional History: AntiFederalists, the Bill of Rights, and the Promise of Post-Modern Historiography." Lau and History Review 12: 1-28. 
Daniels, J. 1997. White Lies Race, Class, Gender, and Sexuality in White Supremacist Discourse. New York: Routledge.

David, P. A. 1959. "The Hero and the Herd in Technological History: Reflections on Thomas Edison and "The Battle of the Systems," Paper presented in the Conference in Honor of David S. Landes. Bellagio. Italy, August 30-September 4.

Dees, M. and J. Corcoran. 1996. Gathering Storm America's Militia Threat. New York: Harper Collins Publishers.

Doughtery, C. 1995. "The Minutemen, The National Guard and the Private Militia Movement: Will the Real Militia Please Stand Up?. The John Marshall Law Review 28: 959985.

Dyer, J. 1997. Harvest of Rage: Why Oklahoma City is Only the Beginning. Boulder, CO: Westview Press.

Ezekiel, R. S. 1995. The Racist Mind: Portraits of American Neo-Nazis and Klansmen. New York, NY: Viking.

"Featured Document: The Emancipation Proclamation." National Archives and Records Administration Online Exhibit Hall, Accessed 11/21/00, available at http://wwu nara.govt exhall/featured-document/emanproc.html.

Flynn, K. and G. Gerhardt. 1989. The Silent Brotherhood: Inside America's Racist Underground. New York, NY: Free Press.

Freeman, S.M., D. Kaminer, and H.A. Loeb. 1995. Anti-Defanation League Lau Report, The ADL Anti-Paramilitary Training Statute: A Response to Domestic Terrorism. New York, NY: The Anti-Defamation League.

Freilich, J. D., N. Almanzar, A. Pichardo, and C.J. Rivera. 1999. "How Social Movement Organizations Explicitly and Implicitly Promote Deviant Behavior: The Case of the Militia Movement." Justice Quarterly 16: 65.5-683.

Hamm, M.S. 1997. Apocalypse in Oklahoma: Waco and Ruby Ridge Revenged. Boston: Northeastern University Press.

Idelson, H. 1996. "Provisions of Terrorism Law." The Congressional Quarterly June: 17131714.

Jones, J. H. 1968. The Minutemen. Garden City, New York: Doubleday.

Kaplan, J. and T. Bjorgo (eds.). 1998. Nation and Race: The Developing Euro-American Racist Subculture. Boston: Northeastern University Press.

Larish, I. A. 1996. "Why Annie Can't Get Her Gun: A Feminist Perspective on the Second Amendment." University of Illinois Law Review 2: 467-508.

Larissa, R.J. 1996. "Paranoia, Patriotism, and the Citizen Militia Movement: Constitutional Right or Criminal Conduct?" The Mercer Lau Review 47: 581-636.

MacLean, N. 1994. Behind the Mask of Chivalry: The Making of the Second Ku Klux Klan. New York, NY: Oxford University Press.

Mann, C.R., and M.S. Zatz. 1998. Images of Color, Images of Crime Readings. Los Angeles: Roxbury Publishing.

Martinez, T. and J. Guinther. 1990. Brotherhood of Murder. New York, NY: Pocket Books

Messerschmidt, J. W. 1997. Crime as Structured Action Gender, Race, Class, and Crime in the Making. Thousand Oaks, CA: Sage Publications

Moncure, Jr., T. M. 1990. "Who is the Militia-The Virginia Ratification and the Right to Bear Arms." Lincoln Law Review 19: 1-25.

Nelson, J. Terror in the Night: The Klan's Campaign against the Jeus. New York, NY: Simon \& Schuster.

Ridgeway, James. 1995. Blood in the Face: The Ku Klux Klan, Aryan Nations, Nazi Skinheads, and the Rise of a New White Culture. Second Edition. New York: Thunder's Mouth Press.

"The Rise and Decline of the Patriots." 2001. Intelligence Report Summer. Montgomery, AL: Southern Poverty Law Center.

Shanahan, S. and S. Olzak. 1999. "The Effects of Immigrant Diversity and Ethnic Competition on Collective Conflict in Urban America: An Assessment of Two Moments of Mass Migration, 1869-1924 and 1965-1993." Joumal of American Ethric History 18: 64-79.

Sims, P. 1978. The Klan. New York, NY: A Scarborough Book

Stark, R. and W.S. Bainbridge. 1980. Networks of Faith: Interpersonal Bonds and Recruitment of Cults and Sects. American Journal of Sociology 85: 1376-1395.

Stern, K. S. 1996. A Force Upon the Plain, The American Militia Movement and the Politics of Hate. New York: Simon and Schuster.

Thompson, J. 1988. My Life in the Klan. Nashville: Rutledge Press.

Wade, W.C. 1987. The Fiery Cross: The Ku Klux Klan in America. New York: Touchstone.

Walker, S., C. Spohn, M. DeLone. 2000. Race Ethnicity and Crime In American The Color of Justice. Second edition. Belmont, CA: Wadsworth. 
Walter, J. 1995. Every Knee Shall Bow: The Truth and Tragedy of Ruby Ridge \& The Randy Weaver Family. New York: Regan Books / HarperCollins.

Williams, D. 1996. "The Militia Movement and Second Amendment Revolution: Conjuring with the People." Comell Law Review 81: 879-952.

Weinberg, L. 1998. "An Oveniew of Right-Wing Extremism in the Western World: A Study of Convergence, Linkage and Identity." In J. Kaplan and T. Bjorgo (eds.), Nation and Race: The Developing Euro-American Racist Subculture, pp. 3-33. Boston: Northeastem University Press. 